\title{
Sensory evaluation of value added sprouts cutlet developed by using Aloe vera (Aloe succotrina) leaves
}

\author{
KumariPriyanka*, Prasad Ranu,** Gupta Alka,*** PariharRubi,* \\ Gangwar Kiran,* Sheikh Sarita**** \\ *M.Sc. Student, **Professor and Head, Assistant Professor ***, Professor and Dean**** \\ Department of Foods and Nutrition, Ethelind School of Home Science, Sam Higginbottom Institute of \\ Agriculture Technology \& Sciences, Allahabad-211007 [U.P.]
}

\begin{abstract}
The present study was undertaken to develop value added food product by incorporating Aloe vera leavesas well as to evaluate organoleptic quality of prepared food product. The product namely Sprouts Cutlet was made by incorporating Aloe vera leaves 10 percent, 15 percent and 20 percent level refers as $T_{1,} T_{2}, T_{3}$ respectively. The product wereorganoleptically evaluated for the colour and appearance, body and texture, taste and flavour and overall accepatability using Nine point Hedonic scale. Sensory evaluation revealed highest score for Overall acceptability for the treatment $T_{1}(8.53)$ that is at 10 percent enrichment. It can be therefore concluded that Aloe vera leaves can be suitably incorporated in various products.
\end{abstract}

Key words: Aloevera leaves, organoleptic, sensory evaluation

\section{Introduction}

The name Aloe vera derives from the Arabic word "Alloeh" meaning "shining bitter substance," while "vera" in Latin means "true. Aloe vera is a plant belonging to the Liliaceae family, of which there are over 360 known species (Vogler, 1999). They are cactus-like perennial succulents and are characterised by stem less, large, thick, fleshy leaves that are lance-shaped and have a sharp apex and a spiny margin (Steenkamp, 2007). Aloe vera contains 75 potentially active constituents: vitamins, enzymes, minerals, sugars, lignin, saponins, salicylic acids and amino acids (Shelton, 1991). It contains vitamins $C$ and E, which are antioxidants. It also contains vitamin B12, folic acid, and choline. Antioxidant neutralizes free radicals. It contains 8 enzymes: aliiase, alkaline phosphatase, amylase, bradykinase, carboxypeptidase, catalase, cellulase, lipase, and peroxidase. Bradykinase helps to reduce excessive inflammation when applied to the skin topically, while others help in the breakdown of sugars and fats. It alsoprovides minerals such as calcium, chromium, copper, selenium, magnesium, manganese, potassium, sodium and zinc. They are essential for the proper functioning of various enzyme systems in different metabolic pathways and few are antioxidants.It provides 4 plant steroids; cholesterol, campesterol, $\beta$-sisosterol and lupeol. All these have anti-inflammatory action and lupeol also possesses antiseptic and analgesic properties.

It also contains salicylic acid that possesses anti-inflammatory and antibacterial properties. Aloe vera plants has potential in pharmaceutical, nutrition and cosmetic industries and hence it can be utilized in food products development.

\section{Materials And Methods}

The present study was conducted in the Nutrition Research Laboratory, Department of Foods and Nutrition, Ethelind School of Home Science, Sam Higginbottom Institute of Agriculture, Technology \& Sciences,(Deemed to be University), (Formerly Allahabad Agricultural Institute) Allahabad.

Samples used: Aloe vera leaves were procured from organic farming of SHIATS and all other ingredients used in the preparation of food product was procured from the local market.

\section{Preparation of the Food Product}

Aloe vera leaves was used for the incorporation into the product namely Sprouts Cutlet. The basic recipes were standardized and served as Control $\mathrm{T}_{0}$. The treatments and replication of the products are shown in Table 1.

\section{Sensory evaluation of the products}

Sensory evaluation of three product was done by a panel of five judges selected from the faculty members of the Department of Foods and Nutrition, Ethelind School of Home Science. The judges were requested to score the products with the help of the nine point hedonic scale score card(Srilakshmi, 2009). 
Sensory evaluation of value added sprouts cutlet developed by using Aloe vera (Aloe succotrina)

\section{Statistical analysis}

The data obtained from sensory evaluationwere statistically analyzed by using analysis of variance technique (two way classification) and critical difference test (Fisher, 1995).

\section{Results And Discussion}

Product developed from Aloe vera leaves.

\section{Sprouts Cutlet}

From the organoleptic scores illustrated in Table 1 for Aloe vera leaves incorporated in Sprouts Cutlet,it can be stated that treatment $\mathrm{T}_{1}$ was most acceptable among all the treatments. Colour obtained a mean score of 8.53 , body and texture 8.46 , Taste and flavour 8.40 and Overall acceptability 8.53 for this level $(10 \%)$ of incorporation.

Table 1. Effect of incorporation of Alovera leaves on organoleptic characteristics of formulated product

\begin{tabular}{|c|c|c|c|c|}
\hline \multicolumn{5}{|c|}{ Parameters } \\
\hline $\begin{array}{c}\text { Control and } \\
\text { Treatments }\end{array}$ & Colour & Body and Texture & Taste and Flavour & Overall Acceptability \\
\hline $\mathbf{T}_{\mathbf{0}}$ & 8.60 & 8.40 & 8.60 & 8.73 \\
\hline $\mathbf{T}_{\mathbf{1}}$ & 8.53 & 8.46 & 8.40 & 8.53 \\
\hline $\mathbf{T}_{\mathbf{2}}$ & 7.86 & 7.83 & 8.06 & 8.06 \\
\hline $\mathbf{T}_{\mathbf{3}}$ & 7.13 & 7.53 & 7.46 & 10.33 \\
\hline F value & $23.5(\mathrm{~S})$ & $4.38(\mathrm{NS})$ & $17.20(\mathrm{~S})$ & 0.67 \\
\hline CD value & 0.48 & - & 0.40 & \\
\hline
\end{tabular}

Fig .1. Overall acceptability of products incorporated with Aloevera leaves at different levels, compared with control

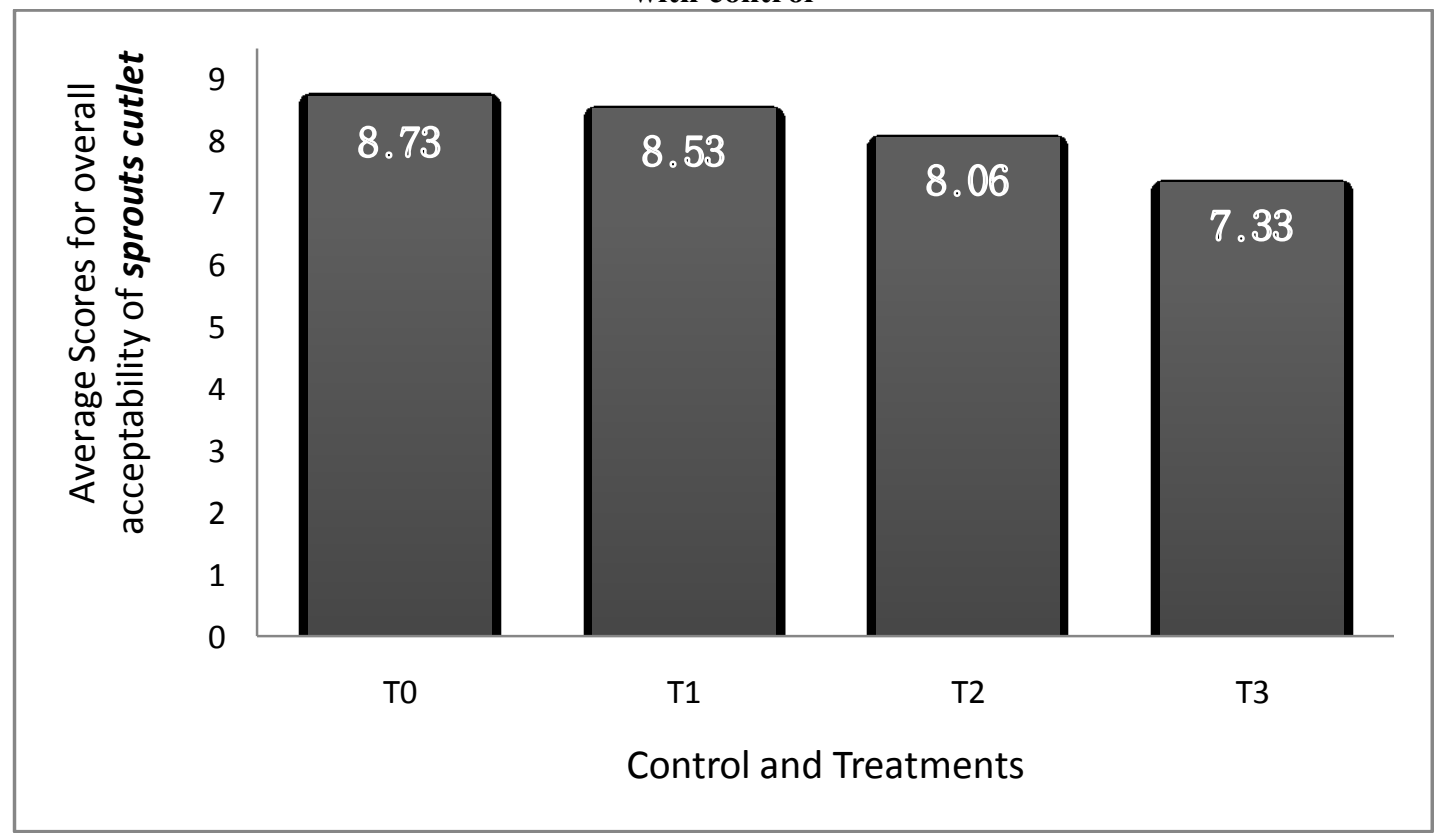

\section{Conclusion}

It may be concluded from the present study that incorporation of Aloe vera leavesin the development of food product like Sprouts Cutlet is well acceptable.On the basis of sensory evaluation treatment $T_{1}(90: 10)$ was best with regard to overall acceptability forthe product.They have sound nutritional and medicinal values. Though the consumption patterns of the Aloe vera leaves are very specific and continued to remain specific, there popularization in the broder range is essential. Specific design of foods acceptable to the population can help in promoting the Aloe vera consumption and therby nutritional intake of the consumers significantly. 


\section{References}

[1]. Fisher R.A. (1995) Statistical methods for research workers: Oliver and Boyd, Edinburbh, Ed. $1^{\text {st }} ; 14: 148-149$

[2]. Shelton M(1991) “Aloe vera, its chemical and therapeutic properties”.'International Journal of Dermatology ;30:679-683.

[3]. Srilakshmi B. (2009)Food Science, Evaluation of Food Quality, $5^{\text {th }}$ Ed., New Age International(P) Limited, $297-298$.

[4]. Steenkamp V, Stewart M(2007) "Medicinal applications andtoxicological activities of aloe products PharmaceuticalBiology" 45(5):411-20.

[5]. Vogler B K and Ernst E (1999) “Aloe Vera: a systematic review of itsclinical effectiveness”. British journal of General Practice ;49(447): 823-828. 